\title{
Dynamic replanning: Some comments on the practical application of the analytical forecast
}

\author{
J.G. Kotzé and N.P. du Preez \\ School of Business Leadership, University of South Africa, Pretoria
}

The importance of formal processes of planning and control in any organization has been recognized for the last two decades. Planning and replanning require some form of forecasting. Unfortunately, most forecasts utilized in practice consist of a complex mix of managerial expectations, organizational momentum, the predicted impact of managerial ac. tions, as well as proposed managerial actions and good intentions. The evaluation of and control over such a forecast is difficult, if not impossible. This has led to efforts to analyse such a forecast into its major components. The practical implementation of these different forecast elements has yielded great success in planning applications. In control applications some undesirable side-effects have become apparent in recent years. A proposed modification to the control system application should eliminate such effects.

S. Afr. J. Bus. Mgmt. 1984, 15: 169-172

Die belangrikheid van formele beplanning- en beheerprosesse vir enige organisasie word al vir die afgelope twee dekades erken. Beplanning en herbeplanning vereis een of ander vorm van vooruitskatting. Ongelukkig bestaan die meerderheid vooruitskattings wat in die praktyk aangetref word uit 'n ingewik. kelde samestelling van bestuursverwagtinge, organisatoriese momentum, die vooruitgeskatte resultate van bestuursaksies, beoogde bestuursaksies en goeie bedoelinge. Die evaluasie van en beheer oor sodanige vooruitskattings is moeilik, indien nie onmoontlik nie. Die voorgaande het gelei tot pogings om vooruitskattings te analiseer in hul belangrikste komponente. Die praktiese implementering van hierdie verskillende vooruitskattingselemente het suksesvolle beplanningsaanwendings opgelewer. Sekere onwenslike newe-effekte in beheeraanwendings is egter prakties ondervind. 'n Voorgestelde modifikasie van die beheersisteem-toepassing behoort hierdie newe-effekte te elimineer.

S.Afr. Tydskr. Bedryfsl. 1984, 15: 169-172

J.G. Kotze* and N.P. du Preez

School of Business Leadership, University of South Africa,

P.O. Box 392, Pretoria 0001, Republic of South Africa

*To whom correspondence should be addressed

\section{Introduction}

In recent years, the processes of corporate planning, business planning, and management control or dynamic replanning have received increasing attention and various authors have emphasized the importance of a structured, formalized process of planning (Argenti, 1983; Schutte, 1980; Schutte 1981; Watson, 1981). To this end, Argenti originally developed the concepts of a mechanistic forecast $\left(F_{o o}\right)$, an analytical forecast $\left(F_{o}\right)$, and an action plan $\left(\mathrm{F}_{\mathrm{p}}\right)$, or action plans $\left(\mathrm{F}_{\mathrm{ps}}\right)$, in the context of corporate planning. $F_{\infty}$ constitutes ' $\ldots$ the simplest form of forecast . . . I shall refer to extrapolations as $F_{\infty}$ forecasts; the double subscript is intended to draw attention to the fact that extrapolation implies that the future will be identical to the past ... nor will the company act to change anything' (Argenti, 1983;219).

The single subscript of the $F_{o}$ 'indicates that this forecast assumes the company does not intend to act to change anything, but that changes in the environment are recognized' (Argenti, 1983:219). The final stage of forecasting, the $F_{p}$, 'is based on the assumptions that both the environment and the company's policy will change (Argenti, 1983:219). Schutte $(1980 ; 1981)$ subsequently extended this application to business planning and management control.

Planning is the structured and well-defined process of decision-making in an organization. With regard to business planning in particular, Schutte states that 'the business planning process consists of a series of distinct steps preceded by an input from the strategic planning process and ending with an output in the form of short-term financial plans or budgets' (Schutte, 1981:68). As stated earlier, it is Schutte's contention that the concepts of $F_{o o}, F_{o}$ and $F_{p s}$ can be applied in this context.

This article concentrates on $F_{o o}, F_{o}$ and $F_{p}$ forecasts in relation to the business planning and control process. In so doing, particular emphasis is placed on the practical application of the analytical forecast or $F_{0}$. It is argued that empirical evidence suggests that, although the $F_{o}$ forecast should be retained in the business planning system, it has certain undesirable side-effects which make its inclusion in the formal management control system of dubious value.

\section{Business planning and forecasting}

In its simplest form, business planning and forecasting involves:

- The identification of the current situation;

- an estimate of the future situation;

- the initiation of some action to achieve an objective (Schutte, 1981). 
The first phase in the business forecasting process, for purposes of business planning and managerial control, is the mechanistic forecast $\left(\mathrm{F}_{\mathbf{o O}}\right)$. It is based on historical performance and is a statistical extrapolation of the current financial situation. The mechanistic forecast is based on the assumptions that the future will be the same as the past and that management will take no action to change this perceived future. The end result, once a particular forecasting technique has been selected, will always be the same; that is, the forecast is not subject to human judgement. Although the practicality of the mechanistic forecast may be questioned, it is the best starting point for the planning process since it clearly indicates the financial position of the company without any human intervention. An illustration of the mechanistic forecast is supplied in Figure 1.

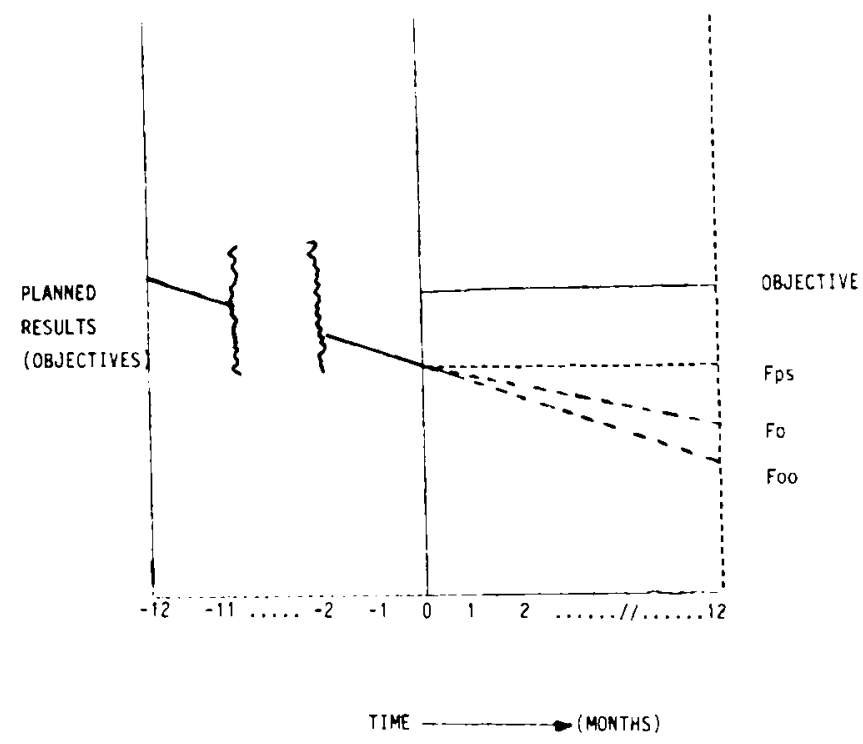

Figure 1 Business forecasting applications in management planning

The second phase in the business forecasting and planning process is the analytical forecast $\left(\mathrm{F}_{\mathrm{o}}\right)$. During this phase the mechanistic forecast is adjusted for anticipated changes in the environment which may have an influence on the organization's performance. These changes may include:

- Environmental influences, i.e. statutory wage increases, increasing fuel prices, changes in interest rates.

- Non-recurring events, i.e. revenue generated from the sale of equipment or the cost of replacing existing equipment.

- Management action carry-over, the effect of which will only become apparent in the future.

The importance of the analytical forecast has been emphasized by both Argenti, (1983:78) \& Schutte (1981:76). An illustration is supplied in Figure 1.

Whereas in the mechanistic forecast, the selected planning base remains constant, the analytical forecast is always subject to managerial judgement. During the planning process, this does not constitute a problem because of the length of the planning cycle, because of the fact that top management will spend some months on the evaluation of the analytical forecast and, finally, because top management can validate the analytical forecast in terms of the strategic and planning assumptions which were employed as a base during the planning phase. By way of contrast, during the control process, the reaction time of management is limited and the validation of updated analytical forecasts must be undertaken within a seriously restricted period.

The third phase in the business forecasting and planning pro- cess is the generation of action plans; in other words, entrepreneurial action or $F_{p s}$ as defined by Argenti (1983). Entrepreneurial action is aimed at changing the probability of future events, to halt negative trends or even to turn negative trends around. This pro-active response of management to future events is also illustrated in Figure 1.

\section{Management control (dynamic replanning)}

The forecasting phases of $F_{o o}, F_{o}$, and $F_{p}$ occupy the same role in the management control process as in the business (management) planning process. The only difference is found in the frequency of development. Whereas the business planning process is typically an annual exercise, management control is usually formally exercised on a monthly basis. This entails a monthly updating of the anticipated results of the current momentum of the organization; an analytical adjustment to allow for the practical impact of environmental changes during the remaining portion of the financial year; and an analysis of the anticipated financial impact of managerial action plans which are aimed at improving the performance of the business unit. This process is illustrated in Figure 2.

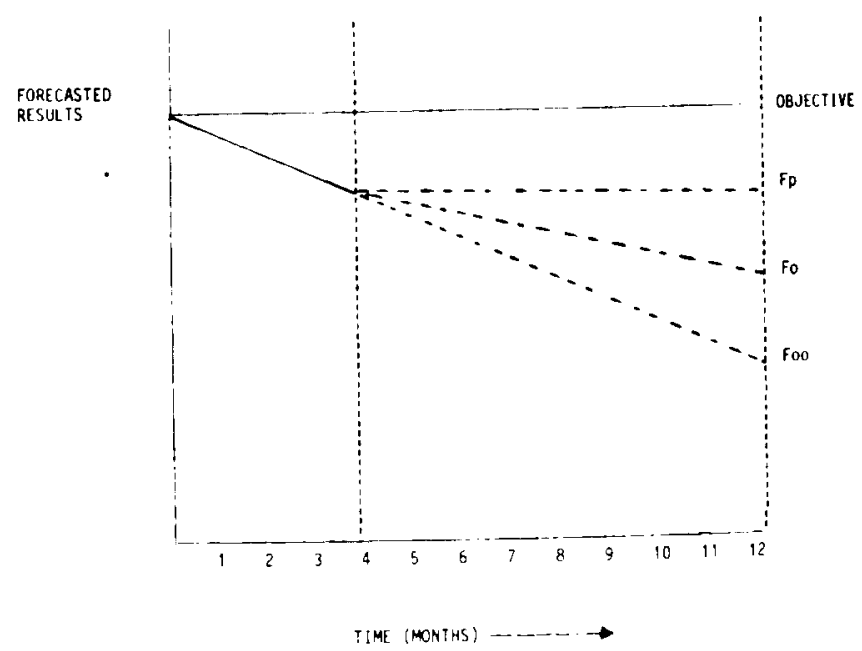

Figure 2 Business forecasting applications in management control

\section{Management control: practical applications}

The successful practical application of the $F_{\infty}, F_{o}$, and $F_{p}$ concepts in numerous South African organizations has attested to the underlying strength of these concepts. The greatest degree of success has been achieved in the business planning application. The application of the forecasting concepts in the management control process has also been quite successful but has, however, yielded an unexpected side-effect: It has become apparent that a major portion of the creative and analytical time of senior-middle and top managers is devoted to the analytical $\left(F_{o}\right)$ adjustment of the $F_{o o}$ extrapolation of the performance of the organizational subunits under their control.

What this means is that the major objective of the management control process; that is, the stimulation of innovative entrepreneurial action on the part of middle and top managers is not being achieved. Instead of accepting the $F_{o o}$ forecast and instituting timeous action to improve on the trends reflected in this extrapolation, these managers are 'explaining' to themselves and to their superiors that the $F_{\infty}$ is wrong and that the original objective (usually embodied as a desirable budgeted result) is still going to be achieved.

It is usually foreseen by these executives that this achieve- 
ment of the desired end result will be brought about by favourable environmental changes. This, in turn, implies that a need for managerial action does not exist.

This phenomenon of unfounded optimism is frequently encountered in human behaviour in general and in managerial behaviour patterns in particular. It has been dubbed the 'Hockey-stick syndrome' and has up to now, in the management control systems context, been associated with the practice of some organizations of making use of a so-called 'updated' or 'year-end forecast' in their budgetary control systems. Schutte scrutinized this issue and discussed the operation of this 'syndrome' in considerable detail (Schutte, 1981:137-139).

As stated previously, empirical evidence now indicates that the same undesirable effect is achieved in the application of management control utilizing the $F_{\infty}, F_{o}$, and $F_{p}$ concepts. In Figure 3 the anticipated and actual sales results of a large South African insurance firm which has utilized the above forecasting concepts for quite a number of years, is reproduced for a particular financial year.

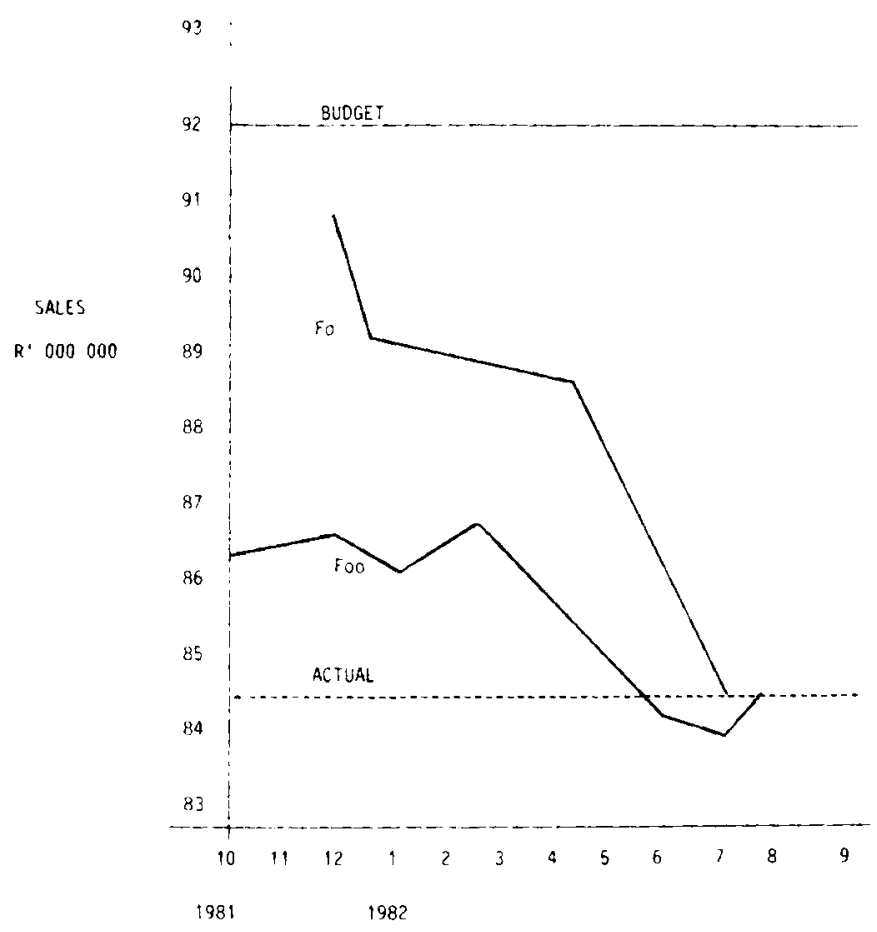

Figure 3 Year-end budgeted and actual sales and monthly updated yearend sales extrapolations

The financial year of this particular organization extends from October to September. The degree of (unwarranted) optimism evidenced by the analytical $\left(\mathrm{F}_{\mathrm{o}}\right)$ forecast up to the end of May is striking.

Figure 4 deals with a major category of expenses for the same organization. Again, the true position as regards the forecast year-end performance is accepted too late for any meaningful managerial action to be taken.

\section{Conclusion}

Similar examples arising from the experiences of other organizations could be cited. However, suffice it to say that the undesirable side-effect of the $F_{o o}, F_{o}$, and $F_{p}$ application, as described, has led to a tentative conclusion that although the $F_{o}$ forecast should be retained in the business planning system, it should not form part of the formal management



Figure 4 Year-end budgeted and actual expenses and monthly updated year-end expense extrapolations

control system. This implies that the documentation forming the structure of the formal management control system should be devoid of any analytical adjustment to the monthly updated mechanistic $\left(F_{o o}\right)$ forecast. Table 1 illustrates the form this prescribed formal documentation should take. The momentum of the organization is extrapolated in the Mechanistic forecast column and any 'performance gap' (Schutte, 1980) between this column and the Annual budget column should be closed or minimized by managerial action documented in the 'Action plans' column. There is no provision for any analytical adjustments to the mechanistic forecast.

It is believed that this approach will remove the major stumbling block to the achievement of the real 'pay-off' of an effective management control system. Schutte (1981:140) has provided a striking description of this pay-off.

'Given the new planning base, the change agents in the organization should develop action programmes to improve on that base, irrespective of the fact that the base may fall short (unfavourable variance) or exceed (favourable variance) the objectives as reflected in the original budget. It follows that the performance of these managers should be measured by their contributions to organizational profits in the form of action programmes developed ....'

The authors contend that this new (re)planning base should be the mechanistic $\left(F_{o o}\right)$ and not the analytical $\left(F_{o}\right)$ forecast. This raises questions about the realism of the $F_{o o}$. Empirical evidence again suggests that doubts about the $F_{o o}$ are valid in the early portion (initial six months) of the financial year but that the $F_{o o}$ usually becomes quite accurate as a predictor of year-end results from the seventh month onwards.

Finally, is the realism of the $F_{\infty}$ a relevant consideration? If it is accepted that the ultimate objective of an effective management control system is the fostering of creative, entrepreneurial action, the $F_{\infty}$ can be regarded as an imperfect, but at the same time, an effective instrument to utilize in the pursuit of this objective. 
Table 1 Example of formal documentation

\section{Operating centre:}

Financial performance report for the period ending:

Reponsible official:

Year to date

Particulars

Revenue

Commission (Services)

Commission (Insurance)

Interest received

Total revenue

Controllable expenses

Printing and stationery

Wages

Maintenance

Postage

Total controllable expenses

Operating centre contribution

$$
\mathbf{A}-\mathbf{B}=
$$

A

\section{Full year}

Projected fi-

Mechanistic Action plans nancial per- Annual Planning formance

\section{Noncontrollable expenses \\ Lease charges \\ Depreciation}

Total noncontrollable expenses

D

Net profit/Loss $C-D=E$

\section{References}

Argenti, J, 1983. Systematic corporate planning. Middlesex: Nelson. Schutte, F.G. 1980. Budgetary control systems for the eighties. J.

Gen. Manage. vol. 5.
Schutte, F.G. 1981. Integrated management systems. Durban: Butterworths.

Watson, C.E. 1981. Results - oriented managing. Reading Massachusetts: Addison-Wesley. 